Review

\title{
Temperature-Responsive Polymer Modified Surface for Cell Sheet Engineering
}

\author{
Zhonglan Tang, Yoshikatsu Akiyama and Teruo Okano * \\ Institute of Advanced Biomedical Engineering and Science, TWIns, Tokyo Women's Medical \\ University, 8-1 Kawada-cho, Shinjuku, Tokyo 162-8666, Japan; \\ E-Mails: zltang@abmes.twmu.ac.jp (Z.T.); yakiyama@abmes.twmu.ac.jp (Y.A.) \\ * Author to whom correspondence should be addressed; E-Mail: tokano@abmes.twmu.ac.jp; \\ Tel.: +81-3-3353-8111 (ext.6201); Fax: +81-3-3359-6046.
}

Received: 23 April 2012; in revised form: 17 July 2012 / Accepted: 30 July 2012 /

Published: 15 August 2012

\begin{abstract}
In the past two decades, as a novel approach for tissue engineering, cell sheet engineering has been proposed by our laboratory. Poly( $N$-isopropylacrylamide) (PIPAAm), which is a well-known temperature-responsive polymer, has been grafted on tissue culture polystyrene (TCPS) surfaces through an electron beam irradiated polymerization. At $37{ }^{\circ} \mathrm{C}$, where the PIPAAm modified surface is hydrophobic, cells can adhere, spread on the surface and grow to confluence. By decreasing temperature to $20{ }^{\circ} \mathrm{C}$, since the surface turns to hydrophilic, cells can detach themselves from the surface spontaneously and form an intact cell sheet with extracellular matrix. For obtaining a temperature-induced cell attachment and detachment, it is necessary to immobilize an ultra thin PIPAAm layer on the TCPS surfaces. This review focuses on the characteristics of PIAPAm modified surfaces exhibiting these intelligent properties. In addition, PIPAAm modified surfaces giving a rapid cell-sheet recovery has been further developed on the basis of the characteristic of the PIPAAm surface. The designs of temperature-responsive polymer layer have provided an enormous potential to fabricate clinically applicable regenerative medicine.
\end{abstract}

Keywords: poly( $N$-isopropylacrylamide); temperature-responsive cell culture surface; cell sheet engineering 


\section{Introduction}

There are many synthetic polymers with molecular structures sensitive to environmental changes, such as $\mathrm{pH}$ [1], electric field [2], chemical species [3], and temperature [4]. Among these polymers, poly $(N$-isopropylacrylamide) (PIPAAm) is a well-known intelligent polymer, which exhibits temperature-responsive soluble/insoluble changes in aqueous solution below and above a lower critical solution temperature (LCST) of $32^{\circ} \mathrm{C}$, respectively [5]. Polymer chains of PIPAAm hydrate to form an expanded structure in water at a lower temperature below LCST. However, the chains form a compact structure by dehydration at a higher temperature above LCST. These transition phenomena of aqueous PIPAAm solution are mainly due to the conformational changes of the polymer chain arising from the hydration changes of isopropyl side groups. Due to this specific property in solution, PIPAAm has been utilized for various biological applications in our laboratory. For example, the coil-globule transition of PIPAAm has provided a new approach to prepare thermo-responsive polymeric particles. The block polymer consisted of PIPAAm as a hydrophilic moiety and poly(n-butylmethacrylate) as a hydrophobic moiety, and forms a stable polymeric core-shell micelle, where PIPAAm chains give the hydrophilic shell, and the stable micellar structure as a drug delivery system collapses when the solution is heated to a higher temperature above LCST of PIPAAm, resulting in drug release [6]. Moreover, a new strategy in high-performance liquid chromatography (HPLC) has been also proposed, and the surface of the silica stationary phase of the HPLC column has been modified with PIPAAm to show its temperature-controlled hydrophilic/hydrophobic changes. Due to the interaction between PIPAAm-modified silica and analytic molecules, the retention times of hydrophobic molecules have been found to increase with increasing temperature without any change in the eluent [7-9].

In this review, another PIPAAm major application developed as an innovative approach for regenerative medicine by our laboratory has been summarized [10-16]. PIPAAm has been grafted on a substrate, which can exhibit a reversible cell adhesion to, and detachment from, the polymer-modified surface in response to temperature. With this surface, cultured cells are able to be harvested as an intact contiguous cell sheet by lowering culture temperature from $37^{\circ} \mathrm{C}$ to $20^{\circ} \mathrm{C}$, and this approach has been called "cell sheet engineering" (Figure 1). Here, this article explains the features of thermo-responsive cell culture surfaces and the mechanism of cell adhesion and detachment in responsive temperature. Furthermore, this article has also introduced various novel functional temperature-responsive cell culture surfaces for clinically applicable regenerative medicine.

Figure 1. The schematic illustration of cell sheet on poly( $N$-isopropylacrylamide) (PIPAAm) modified surface. (a) At $37{ }^{\circ} \mathrm{C}$, cells adhere on dehydrated PIPAAm layer; (b) At $20^{\circ} \mathrm{C}$, cells detach from hydrated PIPAAm layer, and form an intact cell sheet.

(a)

(b)

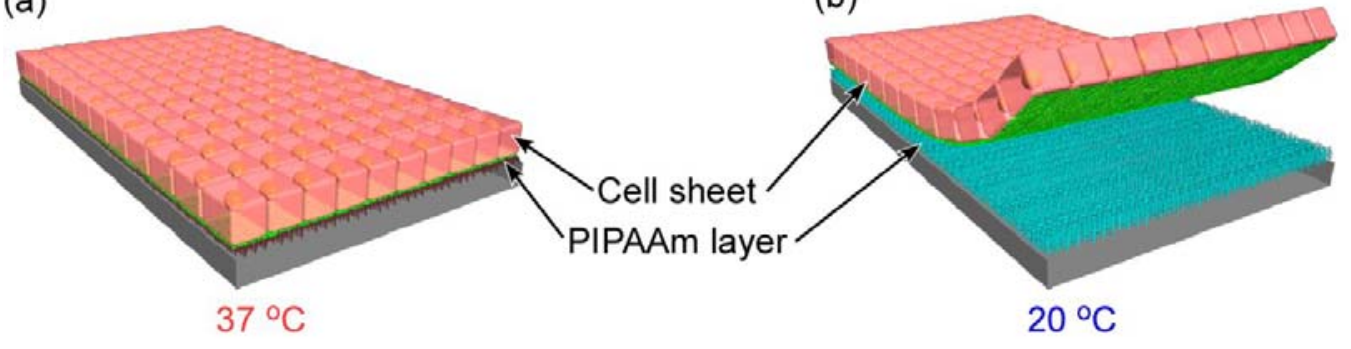




\section{Temperature-Responsive Cell Culture Surface}

\subsection{Ultrathin Poly(N-isopropylacrylamide) Gel Modified Surface for Cell Culture}

Thermo-responsive cell culture surfaces were proposed by our laboratory 20 years ago. PIPAAm was grafted onto the surfaces of commercially available tissue culture polystyrene (TCPS) dishes by electron beam (EB) irradiating polymerization [10,17]. Briefly, $N$-isopropylacrylamide (IPAAm) monomer is dissolved in 2-propanol. This monomer solution $(30 \mu \mathrm{L})$ is spread uniformly over the surfaces of TCPS dishes. These dishes were immediately irradiated with 0.3 MGy EB by using an area EB processing, and PIPAAm was polymerized and grafted on TCPS dishes. Finally, after EB irradiation, PIPAAm-modified dishes were washed extensively with cold Milli-Q water to remove the unreacted IPAAm monomers and unmodified PIPAAm. At a cell culture temperature of $37{ }^{\circ} \mathrm{C}$, PIPAAm chains on the surface of the dish are dehydrated, resulting in a hydrophobic surface, and many kinds of cells, such as epidermal keratinocytes [18], vascular endothelial cells [19], corneal epithelial cells [20], oral mucosal epithelial cells [21], renal epithelial cells [22,23], periodontal ligaments [24,25], hepatocytes [26], and cardiomyocytes [15,27], are able to adhere and spread on PIPAAm gel modified TCPS (PIPAAm-TCPS). No significant difference in the expressions of cell phenotypic markers between cells cultured on PIPAAm-TCPS and commercially available TCPS has been observed. Moreover, cells are also able to proliferate on the PIPAAm-TCPS surface and grow to confluence. Significantly, by reducing the temperature to $20^{\circ} \mathrm{C}$, PIPAAm chains are hydrated, and the surface becomes hydrophilic, cells shrink, due to their cytoskeleton reorganization, and detach from PIPAAm-TCPS spontaneously. In contrast, no cell detachment has been found on commercial TCPS surfaces when the temperature is decreased to $20^{\circ} \mathrm{C}$.

A key factor has been observed for achieving a cell adhesion/de-adhesion on the PIPAAm-TCPS surface by studying the surface properties. As shown in Table 1, two types of PIPAAm layers with different thickness were grafted on TCPS by EB irradiation [28]. One PIPAAm-TCPS has a thinner PIPAAm layer with a lower density of grafted PIPAAm, while the other has a thicker layer with a larger PIPAAm density. The wettability changes were observed in both of the PIPAAm-TCPS surfaces during the temperature change from $37{ }^{\circ} \mathrm{C}$ to $20{ }^{\circ} \mathrm{C}$. However, the surface with a thick and large amount grafted PIPAAm layer showed greater hydrophilicity at both temperatures. On the other hand, cells adhere and spread only on PIPAAm-TCPS with a thin and a small amount of grafted PIPAAm layer at $37^{\circ} \mathrm{C}$, and detach from the surface at $20^{\circ} \mathrm{C}$. In contrast, no cell adhesion has been observed on PIPAAm-TCPS with a thick and a large amount of grafted PIPAAm layer, even at a temperature above LCST.

The contact angle decreases (more hydrophilic), when PIPAAm-TCPS has a high polymer density and thickness (Table 1). In previous studies, the configuration of grafted PIPAAm chains and their mobility is able to affect the wettability of PIPAAm modified surfaces with varying temperatures. Above LCST, PIPAAm layer with liberated mobile chains, such as single terminal grafted surface, exhibits more hydrophilicity [29-31]. In contrast, a PIPAAm layer with a looped and extended chain configuration, such as a multi-point grafted surface, has been found to be more hydrophobic. The non-fixed/cross-linked PIPAAm gel exhibited a higher swelling ratio than that of a single-side fixed/cross-linked one. Moreover, comparing single side fixed/cross-linked PIPAAm hydrogels with 
different thicknesses, the swelling ratio of thinner gel has been found to be less than half of that of a gel with double thickness. These results suggest that the mobility of polymer chains in PIPAAm gel grafted on the substrate has been limited at the interface between polymer chains and substrate, and the interface can produce an extensive hydrophobic aggregation and limit the hydration of the polymer chains. Moreover, the limitation of polymer chain mobility progressively limits a general polymer network responsibility through cross-linked points inside the polymer gel. As a result, PIPAAm chains in the outer region have more free mobility and a greater sensing ability to stimuli than that of the inner region. This principle can extend to PIPAAm-TCPS with an ultra thin PIPAAm layer.

Table 1. Characterizations of poly( $N$-isopropylacrylamide) (PIPAAm) grafted surfaces.

\begin{tabular}{cccc}
\hline Amount of grafted PIPAAm $\left(\mu \mathrm{g} / \mathrm{cm}^{2}\right)^{\mathrm{a}}$ & $1.4 \pm 0.1$ & $2.9 \pm 0.1$ \\
\hline \multicolumn{2}{c}{ Thickness of PIPAAm layer $(\mathrm{nm})^{\mathrm{b}}$} & $15.5 \pm 7.2$ & $29.3 \pm 8.4$ \\
\hline \multirow{2}{*}{ Contact angle $(\cos \theta)^{\mathrm{c}}$} & $20^{\circ} \mathrm{C}$ & 0.42 & 0.50 \\
\cline { 2 - 4 } Cell adhesion & $37^{\circ} \mathrm{C}$ & 0.20 & 0.35 \\
\cline { 2 - 4 } & $20^{\circ} \mathrm{C}$ & non-adhesive & $-{ }^{\mathrm{d}}$ \\
\hline
\end{tabular}

${ }^{a}$ measured by total reflection Fourier transform infrared spectroscopy. $n=4$, mean $\pm \mathrm{SD} ;{ }^{\mathrm{b}}$ measured by atomic force microscopy. $\mathrm{n}=4$, mean $\pm \mathrm{SD} ;{ }^{\mathrm{c}} \mathrm{n}=3$; ${ }^{\mathrm{d}}$ Not determined

The possible chain motilities of PIPAAm-TCPS with thin and thick PIPAAm layers are shown in Figure 2. Above LCST, at the root of PIPAAm layer, PIPAAm chains are highly dehydrated and aggregated due to the extended influence of the hydrophobic basal polystyrene surface (Aggregated region). That aggregation and dehydration gradually extend to the roof region of the PIPAAm layer, which is accompanied with a limitation in chain mobility near the aggregated region (Restricted region). For the thinner PIPAAm layer, the limited mobility in the restricted region has promoted the dehydration of the PIPAAm chains, resulting in a sufficiently hydrophobic outermost surface for cell adhesion. With our studies, a useful PIPAAm gel layer has been considered to be between $15 \mathrm{~nm}$ and $20 \mathrm{~nm}$ to obtain the modulation of cell adhesion/de-adhesion in response to temperature changes. In contrast, for a thicker PIPAAm layer, the dehydration of PIPAAm chains at the outermost surface (Loose region in the right side of Figure 2) are unable to be promoted even above the LCST of PIPAAm, due to weak mobility limitation from the basal polystyrene surface. In previous study, cells have been reported to be unable to adhere on bulk PIAAm hydrogel even at $37{ }^{\circ} \mathrm{C}$. These results suggest a possible mechanism that cells are unable to adhere onto the surface of PIPAAm-TCPS with a thick PIPAAm layer, where dehydrated PIPAAm chains at the outermost region of thicker PIPAAm layer still retain a slight higher mobility_like a free gel. Therefore, controlling PIPAAm layer thickness should be a critical issue to reliably produce a temperature-responsive cell adhesion/de-adhesion surface. The thickness dependency of cell adhesion/de-adhesion behavior has also been proven in another study, where PIPAAm has been grafted onto a piece of glass cover-slip using EB irradiation [32]. No cell adhesion has been observed on the cover slip with a grafted PIPAAm having more than $1.28 \mu \mathrm{m} / \mathrm{cm}^{2}$ density and $7.4 \mathrm{~nm}$ thickness. 
Figure 2. Schematic illustration of the effect of molecular mobility of grafted PIPAAm chains on its adhesion characteristics at $37^{\circ} \mathrm{C}$. The grafted PIPAAm gels are thin (the left side) and thick (the right side). The darker chains denote more restricted molecular motion, while brighter chains suggest greater mobility. The darker and lighter chains show a firmly and loosely restricted molecular motion, respectively.

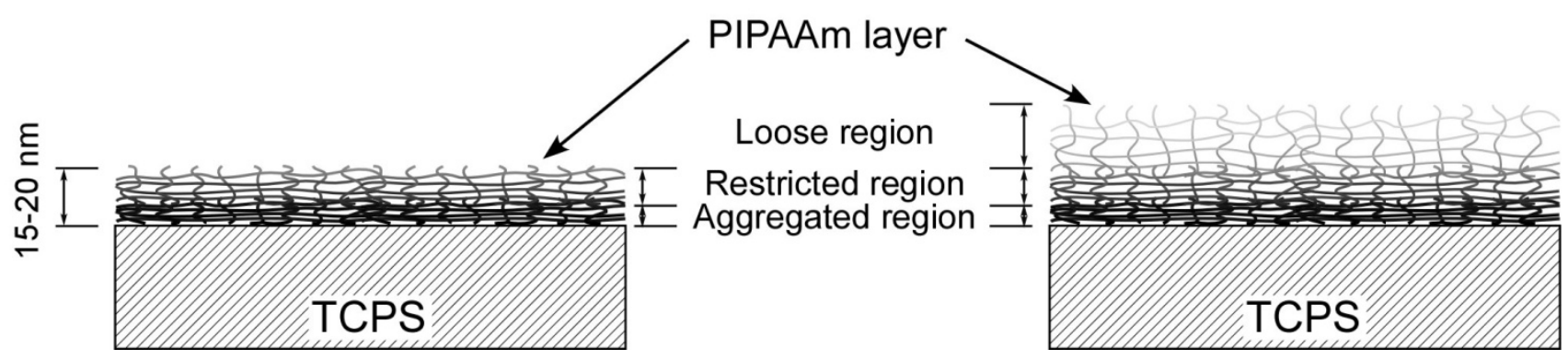

\subsection{Cell Sheet Engineering}

As described above, cells can grow to confluence on PIPAAm-TCPS at $37{ }^{\circ} \mathrm{C}$. By reducing temperature to $20^{\circ} \mathrm{C}$, due to an alteration from a hydrophobic to hydrophilic surface, all the cells can spontaneously detach themselves from the PIPAAm-TCPS surface, and become a single contiguous cell sheet. In previous studies, enzymatic treatment with trypsin, pronase, collagenase, etc. have been used for recovering cultured cells from a cell culture surface, such as TCPS [33]. However, the enzymatic treatment has been found to damage cell membrane by hydrolyzing various membrane-associated proteins and cutting off both cell-cell junction and extracellular matrix (ECM), resulting in cell function impairment [33-35]. In contrast, most membrane proteins could be retained during the cell sheet recovering procedure described above.

As shown in Figure 3a,b, bovine aortic endothelial cells (BAECs) have been cultured on both ungrafted TCPS dishes and PIPAAm-TCPS [36]. Cells have been observed to adhere, spread, and proliferate to confluence on both dishes. Cell morphologies on both dishes were similar to each other. Moreover, immunofluorescence microscopy reveals that F-actin and fibronectin (FN) have been deposited and accumulated on the PIPAAm grafted surfaces during culture. Cells have been found to maintain these proteins after cell sheet detachment (Figure 3c,d). Moreover, actin filament found in the cell sheet can produce a contractile force sufficient to shrink and fold the entire cell sheet automatically (Figure 3c). These results strongly suggest that cells in a cell sheet are free from possible damage mentioned above during the recovery process with a mild temperature change and no enzymatic treatment. Significantly, ECM produced during the cell culture has been retained under the harvested cell sheet, which allows the recovered cell sheet to adhere easily to various surfaces, such as a culture dish, other cell sheets, and the host tissue. Thus, cell sheet can be used in a potential application as an engineered tissue.

Various kinds of cell sheets have been harvested successfully and used in several clinical applications, such as corneal reconstruction [20,21], cardiac tissue reconstruction [37,38], and periodontal regeneration [24,25]. Tissue reconstruction using cell sheet engineering has several advantages over direct cell injection or tissue reconstruction with biodegradable scaffolds; (1) only a mild low temperature treatment for cell detachment without enzyme treatment allows harvested cell 
sheets to retain their complete cellular functions; (2) cell sheets can be attached to the host tissue and even to wound sites via the intact deposited ECM with minimal cell loss (in contrast, significant cell loss has often been observed with direct injection of single cell suspension); (3) fewer inflammatory responses, which are typically observed in the biodegradation of scaffolds, have been observed after the implantation of cell sheets to the host tissue.

Figure 3. Bovine aortic endothelial cell sheets detached from (a) an ungrafted tissue culture polystyrene (TCPS) dish and (b) poly( $N$-isopropylacrylamide) grafted dish after low-temperature treatment. The detached cell sheet was fixed and stained with (c) rhodamine-phalloidin and (d) double-stained with an anti-fibronectin antibody and a fluorescent dye for nuclei. Fibronectin matrix has been found in the cell sheet, and no remnant has been observed on the surface where the cell sheet detached (the right bottom corner in $(\mathbf{d}))$.
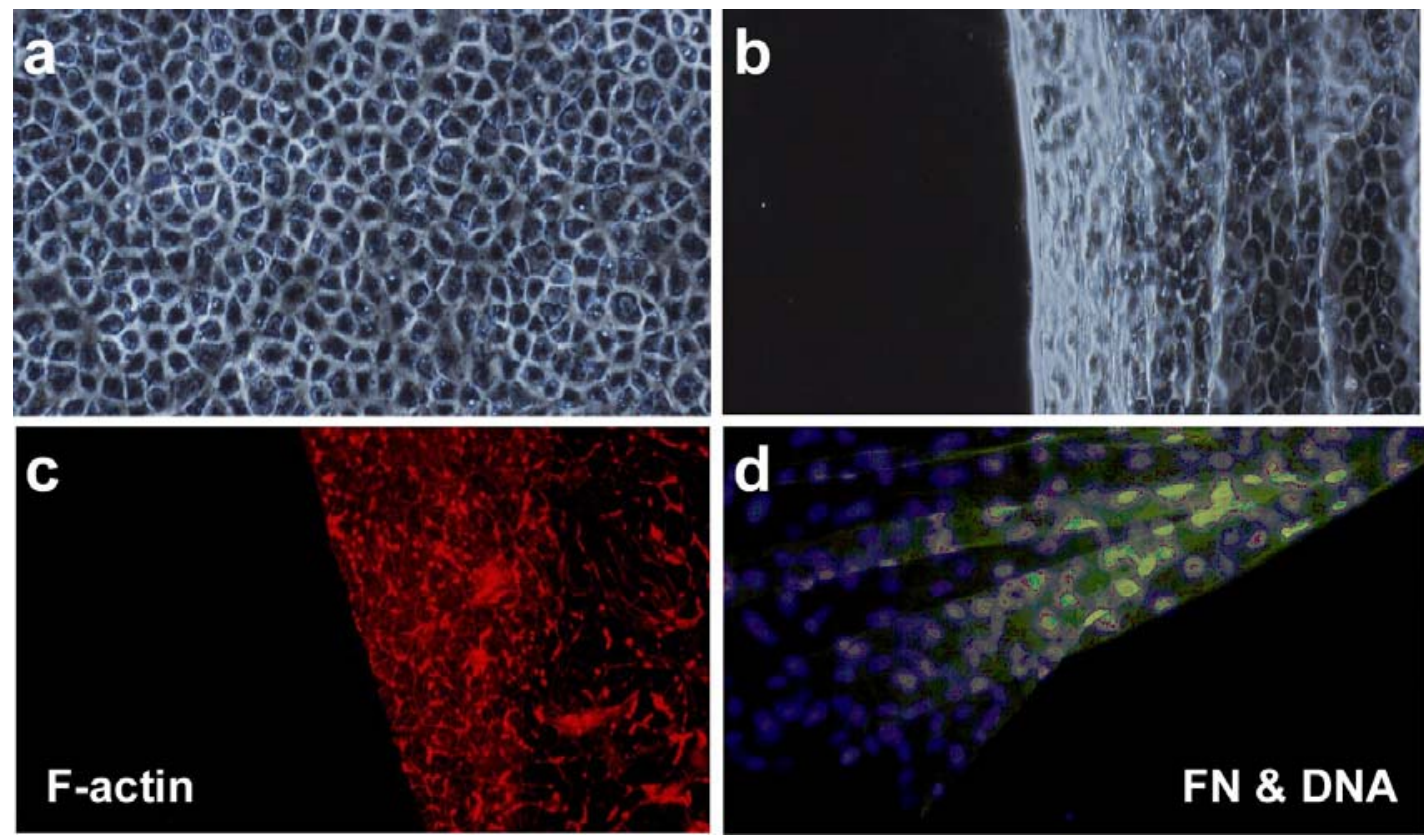

\section{Rapid Recovery of Cell Sheets and Cell Sheet Manipulation Technology}

Although cell sheets with their deposited ECM can be harvested from PIPAAm-TCPS with a low temperature treatment, the detachment process of cell sheet has been found to be a slow process and take 20-30 min or more in a static condition, where grafted PIPAAm chains are gradually hydrated from the periphery of dish towards the central part (Figure 4a). As a result, a long incubation period is required to completely harvest an intact cell sheet at a lower temperature. However, the rapid recovery of the cell sheet is important for maintaining its biological function and the viability of the recovered cell sheet. In addition, it also contributes to the reductions of (1) time, which is necessary for practically assembling tissue structures and (2) patient burden in the clinical step. For accelerating the hydration of PIPAAm layer modified on TCPS, several approaches have been developed by physically modifying the substrate and/or chemically modulating the structures of the PIPAAm gel layer by promoting the hydration of PIPAAm. Furthermore, a hydrogel-coated, plunger-like manipulator has been developed to handle the harvested cell sheet and fabricate a 3D cell-dense tissue. 
Figure 4. Schematic illustration of cell sheet detachment with varying water supply: (a) PIPAAm gel modified tissue culture polystyrene surface (PIPAAm-TCPS); (b) PIPAAm grafted porous membrane (PM) (PIPAAm-PM); and (c) PIPAAm co-grafted with poly(ethylene glycol) (P(IPAAm-co-PEG)) grafted PM (P(IPAAm-co-PEG)-PM).

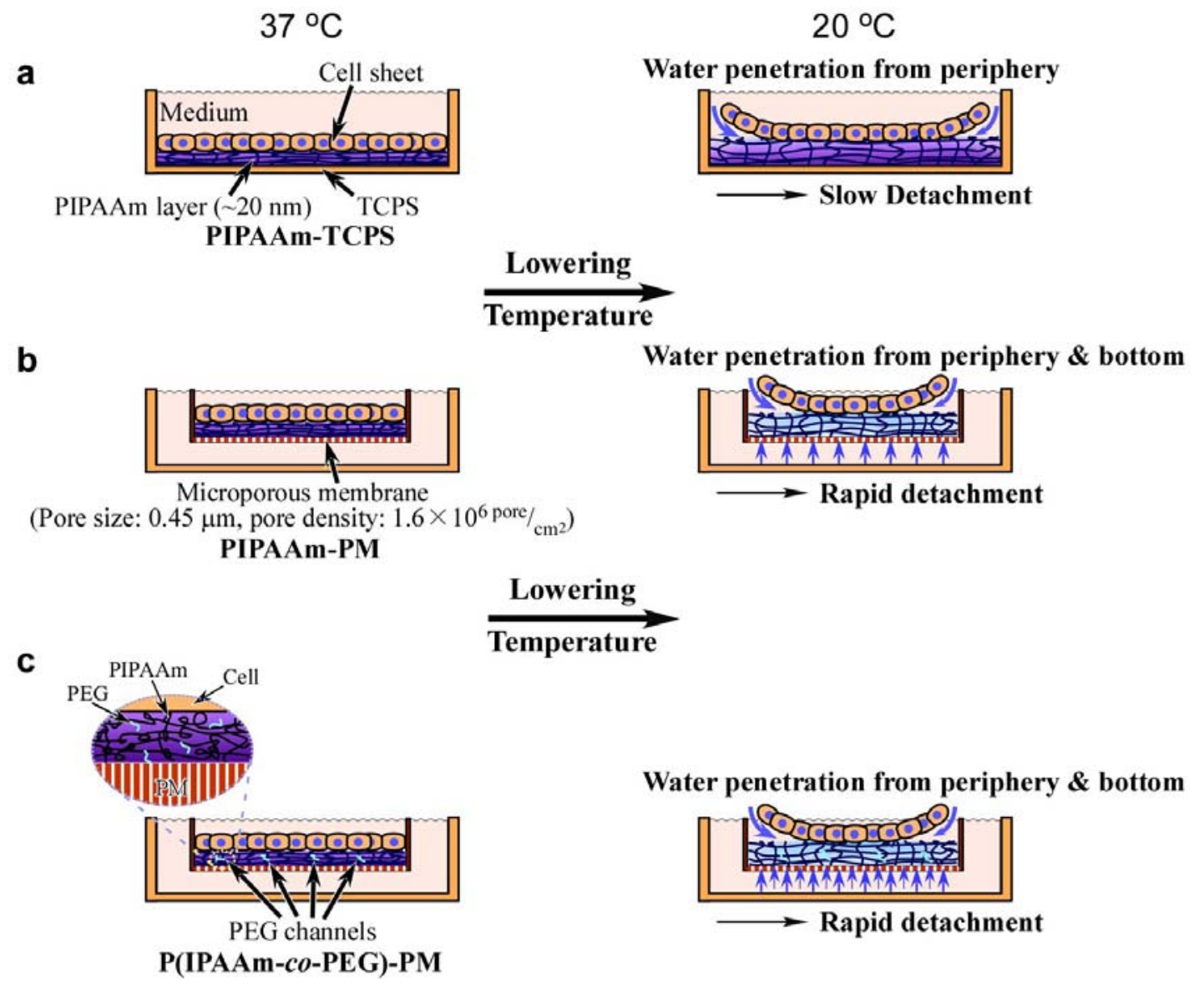

\subsection{Poly(N-isopropylacrylamide) Grafted on Porous Membranes}

As shown in Figure 4b, a simple method has been developed to increase the hydration rate of the polymer. A highly water permeable substrate has been exploited for efficiently supplying water molecules to the interface between cell sheets and the PIPAAm modified surface and for accelerating the hydration of hydrophobic PIPAAm chains beneath the cell sheet. PIPAAm has been covalently grafted onto porous membranes (PMs) (pore size: $0.45 \mathrm{~mm}$, pore density: $1.6 \times 10^{6}$ pores $/ \mathrm{cm}^{2}$, surface area: $4.2 \mathrm{~cm}^{2}$ ) (PIPAAm-PM) by EB irradiation [39]. At $37^{\circ} \mathrm{C}$, BAECs have been found to attach and proliferate on the resultant membrane as well as on a PIPAAm-TCPS. Since the diameter of the pore is smaller than that of a single cell, the cell can adhere and proliferate on the porous membrane without any problem. By reducing temperature below LCST $\left(20{ }^{\circ} \mathrm{C}\right)$, the cells have successfully detached themselves from PIPAAm-PM as a contiguous cell sheet. As expected, the cell sheet detached from PIPAAm-PM more rapidly than PIPAAm-TCPS surface (Figure 5). Compared to the conventional TCPS surface, the hydration of PIPAAm chains have been promoted by water penetration not only from the cell sheet periphery, but also from the pore of the PM under the attached cell sheet, resulting in a rapid detachment of the cell sheet. 


\subsection{Poly(N-isopropylacrylamide) Co-Grafted with Poly(ethylene glycol) onto Porous Membranes}

Several years ago, our laboratory reported the comb-type grafted PIPAAm hydrogel [40,41]. Poly(ethylene glycol) (PEG) chains were grafted into a PIPAAm cross-linked network by co-polymerization of IPAAm and PEG macromonomer, which has been prepared by the etherification reaction of alpha-hydroxy-omega-methoxy-PEG with acryloyl chloride. The resultant PIPAAm hydrogel can exhibit rapid-responsive swelling/de-swelling characteristics while maintaining its polymer transition temperature as observed in homopolymer PIPAAm. Grafted-hydrophilic-PEG chains, which have a mobile terminal and form channels for water molecules, have been found to enhance the rate of hydration of grafted PIPAAm chains, resulting in a rapid swelling/de-swelling gel. Thus, introducing PEG chains into PIPAAm-grafted surfaces has also been expected to achieve rapid cell detachment followed by the rapid hydration of grafted PIPAAm gel, where water penetrates from both the pores of PM and the PEG channels (Figure 4c).

PIPAAm with various amounts of PEG chains has been grafted onto porous membranes by EB irradiation (P(IPAAm-Co-PEG)-PMs), as well as conventional PIPAAm homopolymer grafted onto PMs [42]. Both polymer grafted PM surfaces have been found to exhibit a hydrophilic/hydrophobic alternation by temperature change like PIPAAm-TCPS surface. As shown in Table 2 , at $37{ }^{\circ} \mathrm{C}$, the contact angles of P(IPAAm-Co-PEG)-PMs grafted with 0.1 mol\% PEG in feed (P(IPAAm-co-PEG0.1)-PM) and $0.5 \mathrm{~mol} \%$ PEG in feed (P(IPAAm-co-PEG0.5)-PM) are almost comparable to that of PIPAAm-PM. In contrast, the contact angles of P(IPAAm-co-PEG)-PMs have been found to decrease with an increase in the concentration of PEG in feed at $20^{\circ} \mathrm{C}$. These results suggest that grafted PEG chains scarcely exist in the outermost area of the grafted polymer surface due to hydrophobically contracted PIPAAm chains at $37{ }^{\circ} \mathrm{C}$. Below LCST, embedded PEG chains in the interior of the dehydrated PIPAAm network with a limited mobility are more mobile through the hydration of PIPAAm chains, leading to the rearrangement of PEG chains. BAECs can adhere and grow to confluence on P(IPAAm-Co-PEG)-PM as well as on PIPAAm-PM at $37{ }^{\circ} \mathrm{C}$. However, they have been found to be unable to proliferate to confluency on the higher composition of PEG of (P(IPAAm-Co-PEG1.0)-PM surfaces because of their high hydrophilic property. By reducing temperature to $20{ }^{\circ} \mathrm{C}$, cells have detached themselves as a contiguous cell sheet from P(IPAAm-Co-PEG0.1)-PM, having an optimal copolymer composition more quickly than PIPAAm-TCPS and PIPAA-PM (Figure 5). These results suggest that both the pore beneath the cell sheet and PEG chains have enhanced water diffusion to hydrate PIPAAm surface, resulting in particularly rapid cell sheet detachment.

Table 2. Water contact angle changes of PIPAAm grafted surfaces with temperature.

\begin{tabular}{ccc}
\hline \multirow{2}{*}{ PIPAAm grafted surface } & \multicolumn{2}{c}{ Contact angle $(\cos \boldsymbol{\theta})^{\mathbf{a}}$} \\
\cline { 2 - 3 } & $\mathbf{2 0}^{\circ} \mathbf{C}$ & $\mathbf{3 7}^{\circ} \mathbf{C}$ \\
\hline PIPAAm-PM & $0.633 \pm 0.025$ & $0.528 \pm 0.031$ \\
P(IPAAm-CO-PEG0.1)-PM & $0.711 \pm 0.017$ & $0.543 \pm 0.025$ \\
P(IPAAm-Co-PEG0.5)-PM & $0.754 \pm 0.023$ & $0.536 \pm 0.016$ \\
\hline \multicolumn{2}{c}{${ }^{\mathrm{a}} \mathrm{n}=6$, mean $\pm \mathrm{SD}}$.
\end{tabular}


Figure 5. The average attached areas of BAEC sheets harvested from PIPAAm gel modified tissue culture polystyrene surface (close squares), PIPAAm grafted porous membrane (PM) (close circles) and poly( $N$-isopropylacrylamide-co-ethylene glycol) grafted PM (open circles) at $20^{\circ} \mathrm{C}$.

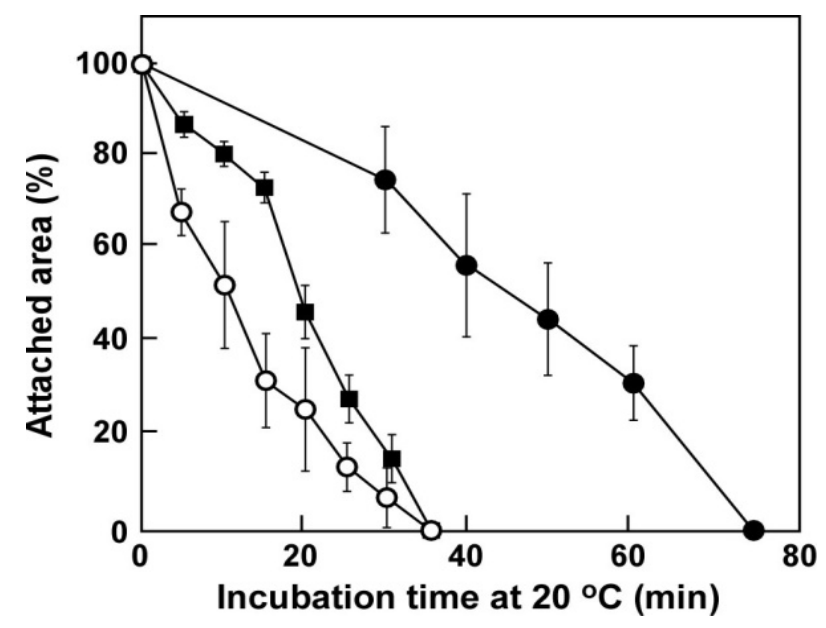

\subsection{Comb-Type Grafted Poly(N-isopropylacrylamide) Gel Modified Surface}

In previews studies, another comb-type grafted PIPAAm hydrogel, which contain PIPAAm graft chains with a freely mobile end and show unique behavior enhancing the swelling/de-swelling rate of the hydrogel in response to temperature change, has been proposed by our laboratory. Above LCST, the graft chains dehydrate and aggregate faster than a conventional PIPAAm cross-linked network, due to the freely mobile end of graft polymer. As a result, PIPAAm cross-linked network shrinks more quickly due to hydrophobic clusters forming inside the polymer network by PIPAAm chains with freely mobile ends, and water is rapidly excluded from the gel (Figure 6a) [43]. In contrast, below LCST, the graft polymer chains are hydrated faster, inducing the rapid hydration and swelling of PIPAAm gel (Figure 6b) [44]. Due to this unique characteristic, a comb-type grafted PIPAAm gel modified surface has been newly developed for providing a rapid cell sheet recovery (Figure 6c) [45].

Firstly, PIPAAm polymer with a terminal hydroxyl end group was synthesized by the radical telomerization of IPAAm monomer using 2-mercaptoethanol as a chain transfer agent. PIPAAm macromonomer has been prepared by the etherification reaction of hydroxyl terminal moiety of PIPAAm with acryloyl chloride. IPAAm with PIPAAm macromonomer has been grafted onto TCPS by EB irradiation, resulting in a comb-type grafted PIPAAm gel modified TCPS (ctPIPAAm-TCPS). Besides a difference in the amount of modified PIPAAm, no distinct difference has been found between the properties of ctPIPAAm-TCPSs and conventional PIPAAm-TCPS. At $37{ }^{\circ} \mathrm{C}$, BAECs have been found to adhere well and spread on ctPIPAAm-TCPS with various concentrations of PIPAAm macromonomers as well as PIPAAm-TCPS. By lowering temperature to $20{ }^{\circ} \mathrm{C}$, BAECs have detached themselves more rapidly from ctPIPAAm-TCPS than from PIPAAm-TCPS. For PIPAAm-TCPS, approximately $55 \mathrm{~min}$ is required for complete cell sheet detachment. In contrast, ctPIPAAm-TCPS with the larger amount of the PIPAAm graft chain has attained more rapid cell sheet detachment (30 $\mathrm{min}$ for ctPIPAAm-TCPS with $1.0 \mathrm{wt} \%$ macro-monomers in feed (1.0 ctPIPAAm-TCPS), and $25 \mathrm{~min}$ for ctPIPAAm-TCPS with $5.0 \mathrm{wt} \%$ macro-monomers in feed 
(5.0 ctPIPAAm-TCPS)) (Figure 7). These results suggest that upon lowering temperature, the grafted polymer chains are speculated to accelerate the hydration of modified PIPAAm gel, resulting in a rapid cell sheet detachment. Significantly, comparing to PEG introduced PIPAAm-TCPS, increasing the concentration of PIPAAm macromonomer has effectively promoted cell sheet detachment without weakening cell adhesion.

Figure 6. Schematic drawing of (a) de-swelling; (b) swelling of comb-type grafted PIPAAm gel and (c) the swelling of comb-type grafted PIPAAm gel modified surface.

a) Deswelling of comb-type grafted PIPAAm gel
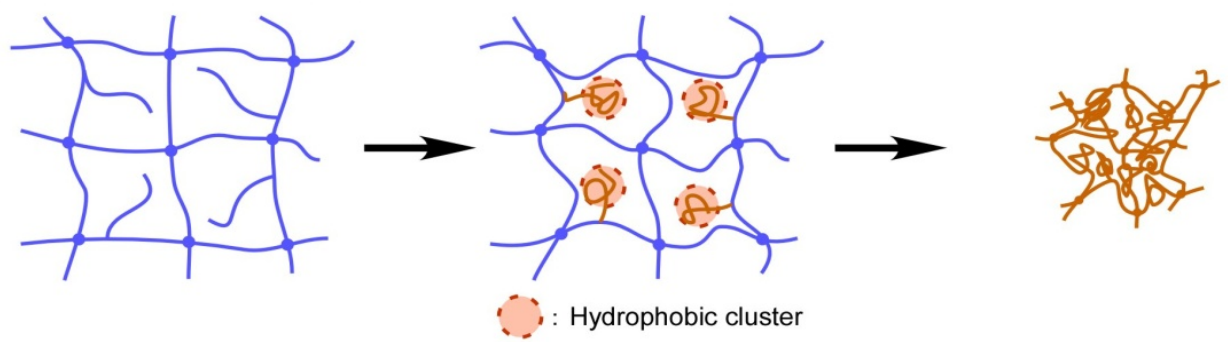

b) Swelling of comb-type grafted PIPAAm gel
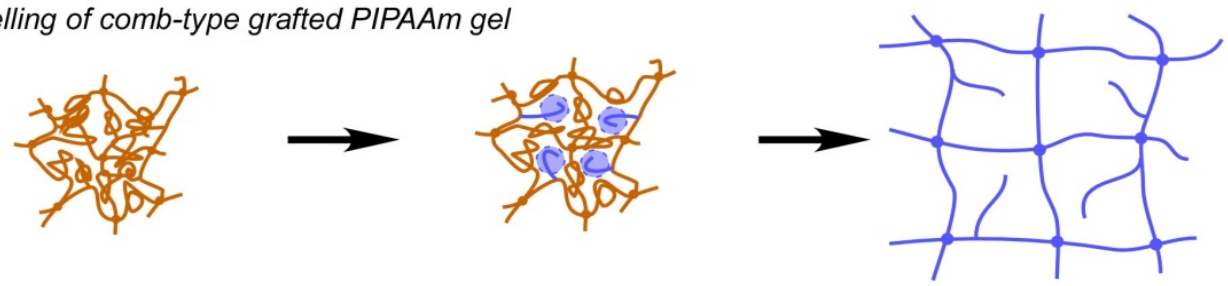

c) Swelling of comb-type grafted PIPAAm-TCPS
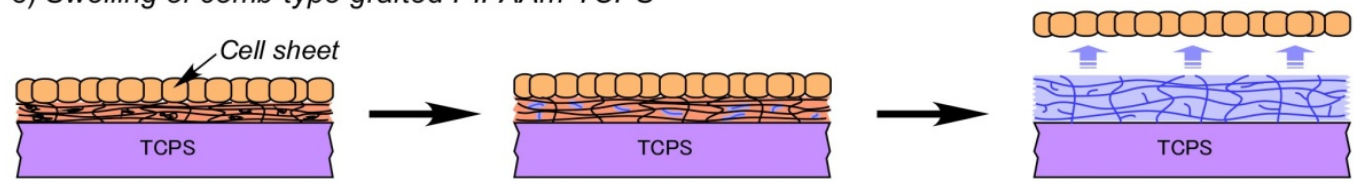

Figure 7. Macroscopic view of cell sheet detachments from (a) PIPAAm gel modified tissue culture polystyrene (TCPS) dish (PIPAAm-TCPS); (b) comb-type grafted PIPAAm gel modified TCPS with $1.0 \mathrm{wt} \%$ macromonomers (1.0 ctPIPAAm-TCPS) and (c) comb-type grafted PIPAAm gel modified TCPS with $1.0 \mathrm{wt} \%$ macromonomers (5.0 ctPIPAAm-TCPS) at $20{ }^{\circ} \mathrm{C}$. Scale bar: $10 \mathrm{~mm}$.
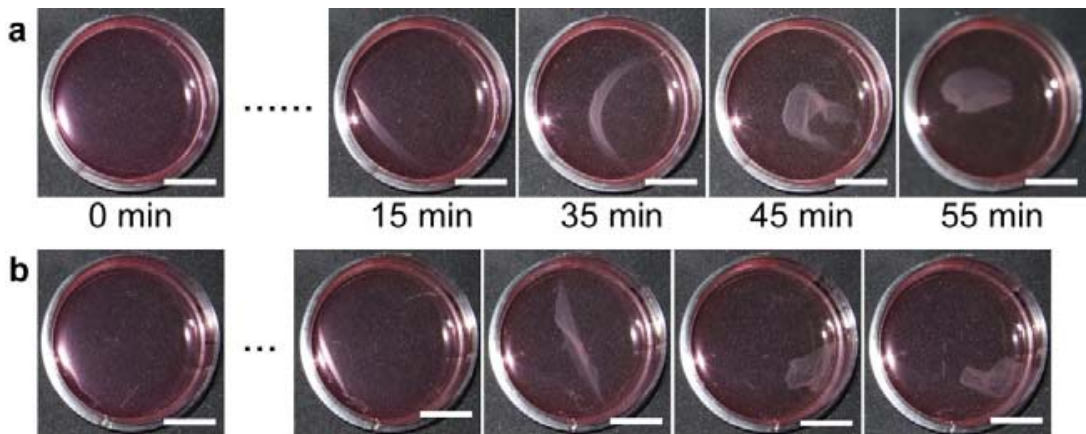

$35 \mathrm{~min}$

$45 \mathrm{~min}$

55 min

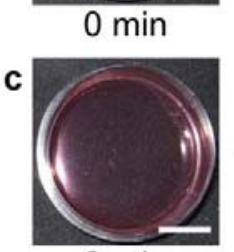

$15 \mathrm{~min}$
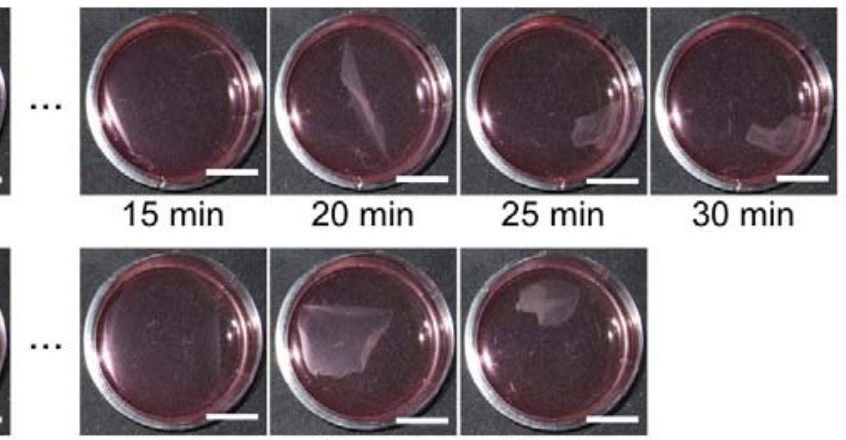

0 min

$15 \mathrm{~min}$

20 min

25 min 


\subsection{Fabrication of 3D Cell-Dense Tissue Using a Manipulator}

Cell sheet detachment processes have been accelerated by various copolymer-modified surfaces mentioned above. However, harvested cell sheets usually shrink, wrinkle and fold themselves during the detachment processes. For harvesting a flat and extended cell sheet and/or fabricating three-dimensional (3-D) cell-dense tissue, a manipulator has been developed (Figure 8e) [46]. As shown in Figure 8, either fibrin or gelatin gel made by a silicone mold has been used as a supporting material for adhering cell sheets. A cell sheet manipulation system consists of supporting hydrogel, a silicone rubber mold, and a plunger-like manipulator. Because both hydrogels fabricated at optimum concentrations tightly adhere to various kinds of cells, cell sheets on a PIPAAm-TCPS could be recovered easily with a combination of the manipulator and low-temperature treatment $\left(20{ }^{\circ} \mathrm{C}\right)$ (Figure 8a,b). A cell sheet can be recovered with a manipulator without shrinkage by this method. The recovered cell sheet attached on the supporting hydrogel is thinner and has a larger surface area than cell sheet detaching spontaneously. With the manipulator, the harvested cell sheet can be transferred to another cell culture device, and ECM in the basal side of cell sheet can adhere on the new surface (Figure 8c). Three-dimensional tissue can also be fabricated by layering cell sheets repeatedly, and the layered cell sheets have been connected to each other through ECM (Figure 8d). The fabricated tissue adhering to the hydrogel can be easily handled and transplanted reproducibly.

Figure 8. Schematic illustration of cell sheet recovery process for cell sheet transferring and three-dimensional tissue fabrication. (a) cell sheet has been covered by a hydrogel-coated manipulator and incubated at $20{ }^{\circ} \mathrm{C}$; (b) cell sheet has been harvested by the manipulator; (c) the harvested cell sheet has been transferred to a new cell culture device; (d) the harvested cell sheet has been layered on another cell sheet; (e) macroscopic view of a cell sheet manipulation system.

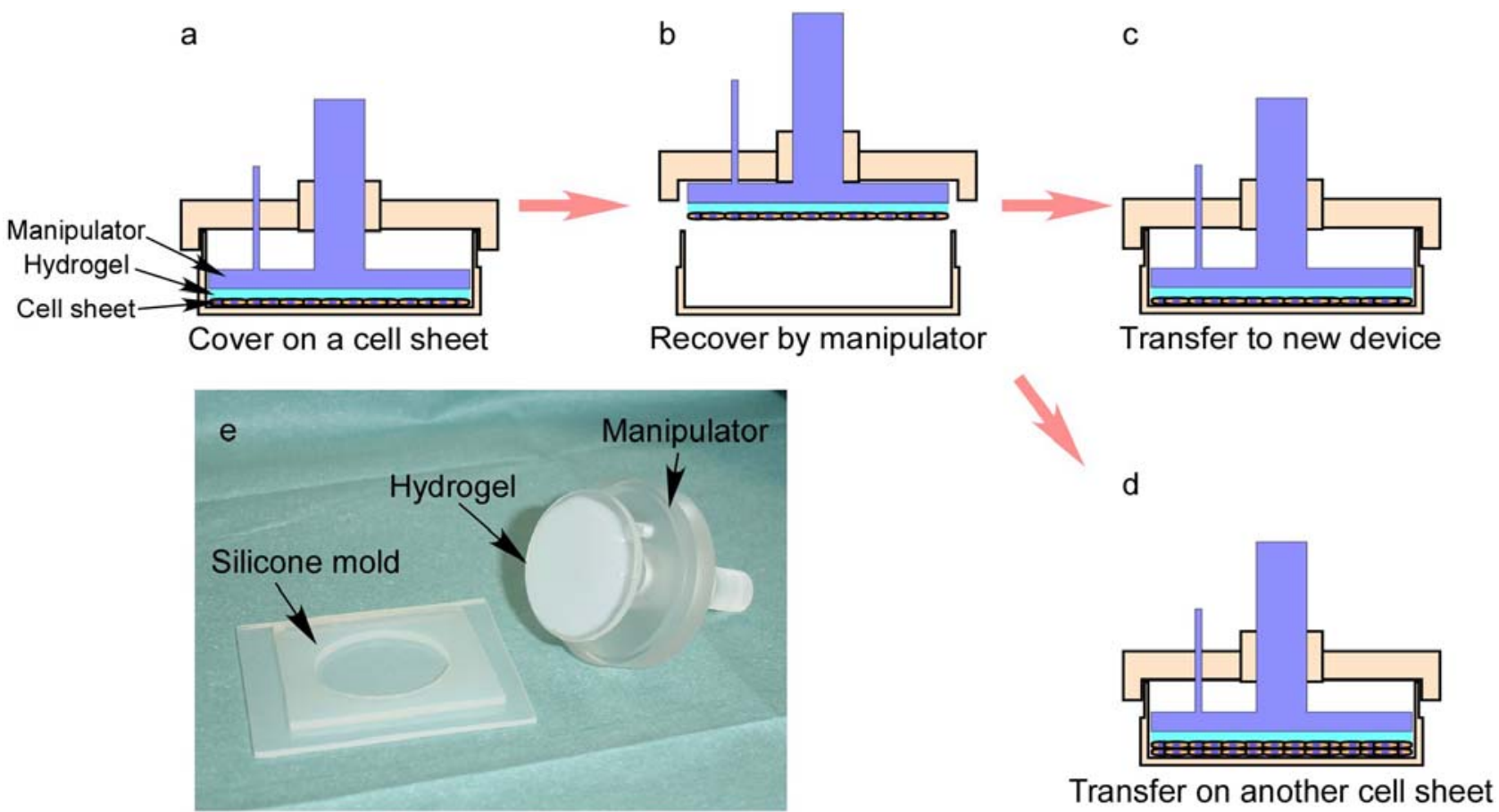




\section{Functionalization of Temperature-Responsive Cell Culture Surfaces}

\subsection{Patterned Temperature-Responsive Polymer Modified Surface}

Heterotypic cell-to-cell interactions are crucial to achieve and maintain specific functions in many tissues and organs [47]. A previous report [48] has suggested that the co-culturing of parenchymal hepatocyte with endothelial cells has a positive effect on continuous hepatic albumin expression, because this culture condition reflects the environment of hepatocytes along sinusoids in liver lobules. Due to the limitation of unitary PIPAAm-TCPS, a 3-D tissue structure has been constructed for co-culture conditions, where an endothelial cell sheet is layered onto a heterotypic cell sheet directly by the manipulator mentioned above. The resultant double-layered structure showing a hepatic albumin expression has been maintained for a prolonged culture period more than one month. To mimic heterotypic cellular interactions, a patterned-surface modification technique has been developed for co-culturing heterotypic cells and endothelial cells for harvesting a patterned co-cultured cell sheet.

The LCST of polymers is well known to be modulated by copolymerizing IPAAm with a hydrophobic or hydrophilic monomer [49-52]. Thus, to induce cell attachment/detachment at a lower temperature, IPAAm has been copolymerized with a hydrophobic monomer, n-butyl methacrylate (BMA), and grafted to TCPS by EB irradiation [53]. The transition temperatures of resultant P(IPAAm-Co-BMA)-grafted TCPS surfaces are found to be reduced with increasing BMA content. Cells have adhered and proliferated to confluence on P(IPAAm-Co-BMA) modified TCPS in a similar manner to PIPAAm-TCPS at $37^{\circ} \mathrm{C}$. Although, after the confluence, cells have successfully detached themselves as a contiguous cell sheet from both PIPAAm-TCPS and P(IPAAm-Co-BMA)-TCPS by reducing temperature to $20{ }^{\circ} \mathrm{C}$, a longer incubation period is required for complete cell detachment with increasing BMA content in the copolymers. Moreover, at $28{ }^{\circ} \mathrm{C}$, the detachments of cell monolayers are observed from only PIPAAm-TCPS and P(IPAAm-Co-BMA)-TCPS with 1.0 mol \% BMA introduced-grafted copolymer (P(IPAAm-Co-BMA)-TCPS-IB1), while no cell monolayer detaches from either P(IPAAm-Co-BMA)-TCPS-IB3 or P(IPAAm-Co-BMA)-TCPS-IB5 surfaces. P(IPAAm-Co-BMA)-TCPS-IB3 and P(IPAAm-co-BMA)-TCPS-IB5 surfaces have remained hydrophobic at this temperature due to a reduction in the transition temperature of the surface as a result of the incorporation of the BMA unit. In sharp contrast, the complete harvests of cell sheets from P(IPAAm-Co-BMA)-TCPS-IB3 and P(IPAAm-Co-BMA)-TCPS-IB5 surfaces have also been observed at $25{ }^{\circ} \mathrm{C}$ and $20{ }^{\circ} \mathrm{C}$, respectively. These results suggest that cell attachment and detachment can be controlled at a specific temperature by varying BMA content incorporated into PIPAAm-TCPS. Namely, cells can adhere on a P(IPAAm-Co-BMA) modified surface at lower incubation temperature, at which cells are unable to adhere to the PIPAAm modified surface.

This new technique has been applied to the preparation of a patterned polymer modified surface for cell co-culture. BMA has been incorporated into a specific surface area on PIPAAm-TCPS with a metal mask with $1 \mathrm{~mm}$ holes by EB irradiation [54]. The resultant surface has consisted of PIPAAm-grafted and P(IPAAm-BMA) co-grafted domain and exhibited patterned dual temperature-responsive properties. At $27{ }^{\circ} \mathrm{C}$, seeded rat primary hepatocytes (RPHCs) have been found to adhere selectively onto hydrophobic, dehydrated P(IPAAm-BMA) domains (approximately $1 \mathrm{~mm}$ in diameter), but fails to adhere onto neighboring hydrated PIPAAm domains (Figure 9a). 
Sequentially seeded BAECs have adhered exclusively to hydrophobic PIPAAm domains with increasing culture temperature to $37^{\circ} \mathrm{C}$, achieving patterned co-cultures (Figure 9b,c). As a result, a patterned cell monolayer consisting of RPHCs and BAECs with heterotypic cell interactions has been harvested by lowering temperature to $20^{\circ} \mathrm{C}$, where both P(IPAAm-BMA) domains and PIPAAm domains have become hydrophilic (Figure 9d). Moreover, immunofluorescent studies have confirmed the albumin synthesis of RPHCs, suggesting that RPHCs are perfectly preserved during culture at $27^{\circ} \mathrm{C}$.

Figure 9. Patterned dual temperature-responsive surface for the co-culture of rat primary hepatocytes (RPHCs) and bovine aortic endothelial cells (BAECs). (a) RPHCs have adhered and proliferated on poly( $N$-isopropylacrylamide- $n$-butyl methacrylate) (P(IPAAm-BMA)) co-grafted domain at $27{ }^{\circ} \mathrm{C}$; (b) BAECs have adhered and proliferated on PIPAAm-grafted domain at $37{ }^{\circ} \mathrm{C}$ and been co-cultured with RPHCs; (c) the magnified view of the periphery of patterned co-cultures (the black square region in (b)); (d) a co-cultured cell sheet is detaching itself from the patterned culture surface. Scale bars: (a), (b), and (d): $0.5 \mathrm{~mm}$ and (c): $0.2 \mathrm{~mm}$.

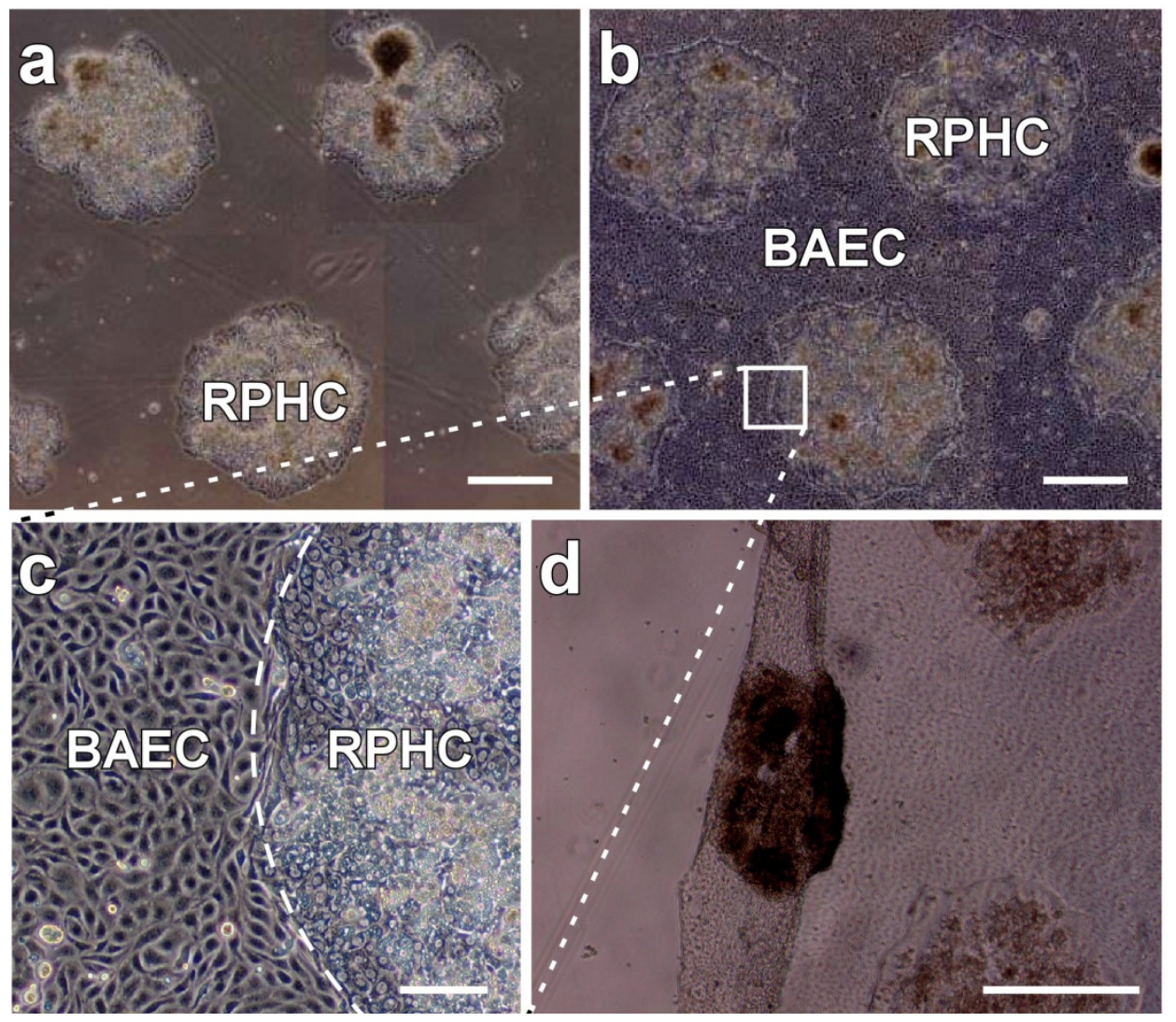

\subsection{Fabricating Biomolecule on Temperature-Responsive Polymer Modified Surface}

For enhancing the cellular functions and metabolisms of cultured cells, it was attempted to introduce biomolecules, such as cell adhesive peptides and cell growth factors, onto the cell culture surface. However, the molecules are unable to be introduced into temperature-responsive PIPAAm-TCPS surface directly, because possible free radicals generated during EB irradiation can damage biomolecules themselves and/or their structures. To conjugate various bioactive molecules in 
PIPAAm gel layer, reactive moiety such as acrylic acid (AAc) has been introduced into PIPAAm [55]. However, a biomolecule introduction not only moves the phase transition temperature of PIPAAm but also dampens the sharp phase transition of resultant copolymer. For overcoming these shortcomings, newly-synthesized 2-carboxyisopropylacrylamide (CIPAAm), which has a side chain structure similar to that of IPAAm, and a functional carboxylate group, has been used as a functional monomer to introduce a biomolecule [56]. The resultant P(IPAAm-Co-CIPAAm) shows a steep phase transition in response to temperature, and the LCST has been found to be almost the same as that of PIPAAm.

Temperature-responsive P(IPAAm-CO-CIPAAm) copolymer has been grafted on TCPS by EB irradiation (PIC-TCPS) [57]. Arg-Gly-Asp-Ser peptide (RGDS), which is found in FN, type I collagen, and other ECM proteins, has been modified on the resultant surface through the reactive carboxyl groups of CIPAAm (RGDS-PIC-TCPS) [57]. The surface with 1\% CIPAAm has been found to promote the spread of human umbilical vein endothelial cells (HUVECs) without fetal bovine serum (FBS) at $37^{\circ} \mathrm{C}$, whereas few cells spread even on TCPS (Figure 10). Moreover, the adhering cells have detached themselves spontaneously by lowering the temperature to $20^{\circ} \mathrm{C}$. These results indicate that the binding of cell integrins to modified RGDS on cell culture substrates can be dissociated by a mild environmental stimulation of temperature, without enzymatic or chemical treatment, due to the shielding of hydrated polymer chains. These findings are important to control the specific interaction between proteins and cells, and the subsequent "on-off" regulation of their function [56,58-60]. Furthermore, because the method allows a serum-free cell culture and a trypsin-free cell harvest to be realized, it should be an attractive cell culture method that requires no mammalian-sourced component.

Figure 10. Comparisons of human umbilical vein endothelial cells (HUVECs) spreading on tissue culture polystyrene surface (TCPS) and Arg-Gly-Asp-Ser peptides (RGDS) modified poly( $N$-isopropylacrylamide-co-2-carboxyisopropylacrylamide) grafted TCPS (RGDS-PIC-TCPS) after 6 and $24 \mathrm{~h}$ cultures with or without fetal bovine serum (FBS) at $37{ }^{\circ} \mathrm{C}$.

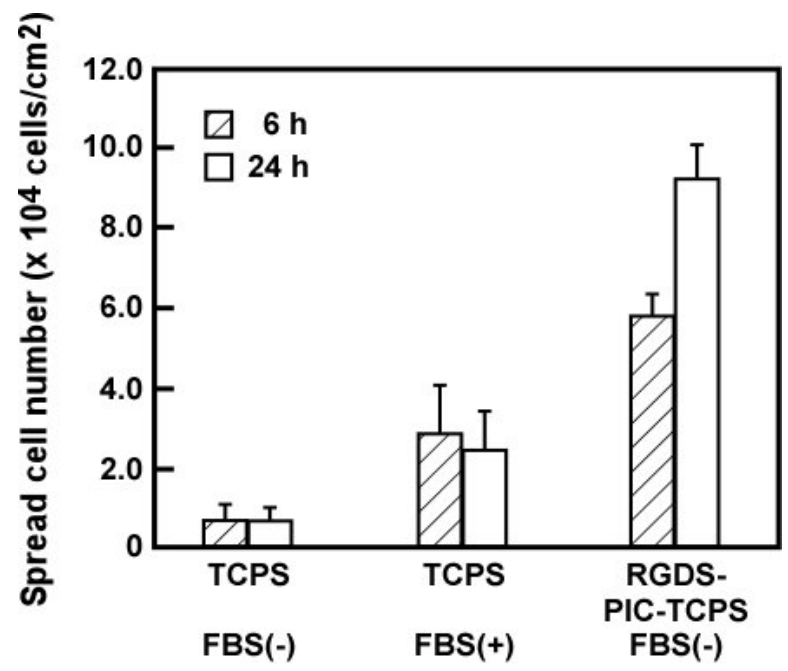

4.3. Micropatterned Temperature-Responsive Polymer Brush Surfaces for Fabricating Cell Sheets with Well-Controlled Orientational Structures

Recently, a new approach for preparing a temperature-responsive cell culture surface has been developed in our laboratory by a living radical polymerization, reversible addition-fragmentation chain 
transfer radical (RAFT) polymerization, which is well known to control the molecular weights of polymers precisely, resulting in polymer having a controlled chain length [61]. With this new approach, a cell adhesion/de-adhesion surface can be prepared easily by varying polymerization time. Moreover, a "living" reactive group has been reserved in the terminal of polymer chain, which can produce various block copolymers via multistep RAFT polymerization [62,63]. Utilizing this unique property, a micropatterned temperature-responsive polymer brush surface has been fabricated to obtain a cell sheet with a well-controlled orientational structure [64].

As shown in Figure 11, a micropatterned polymer brush surface has been prepared by using a combination of surface-initiated RAFT polymerization and photolithography technique. Firstly, PIPAAm brush surfaces have been prepared through surface-initiated RAFT polymerization using azoinitiator-immobilized glass substrates. After photoresist coating and development process, the RAFT-related dithiobenzoate (DTB) groups at grafted PIPAAm termini have been partially substituted by inert maleimide groups for preventing further polymerization to form the PIPAAm brush regions. After removing the residual photoresists from all regions, poly $(N$-acryloylmorpholine) (PAcMo) has been grafted as the "second block" from the reserved reactive terminal of grafted PIPAAm chains to form the PIPAAm- $b$-PAcMo regions, resulting in a striped, micropatterned temperature-responsive polymer brush surface.

Figure 11. Schematic illustration of preparing a micropatterned temperature-responsive polymer brush surface via two-step reversible addition-fragmentation chain transfer radical (RAFT) polymerization. Poly( $N$-acryloylmorpholine) (PAcMo) segments have been grafted from PIPAAm blocks through reserved dithiobenzoate (DTB) groups.

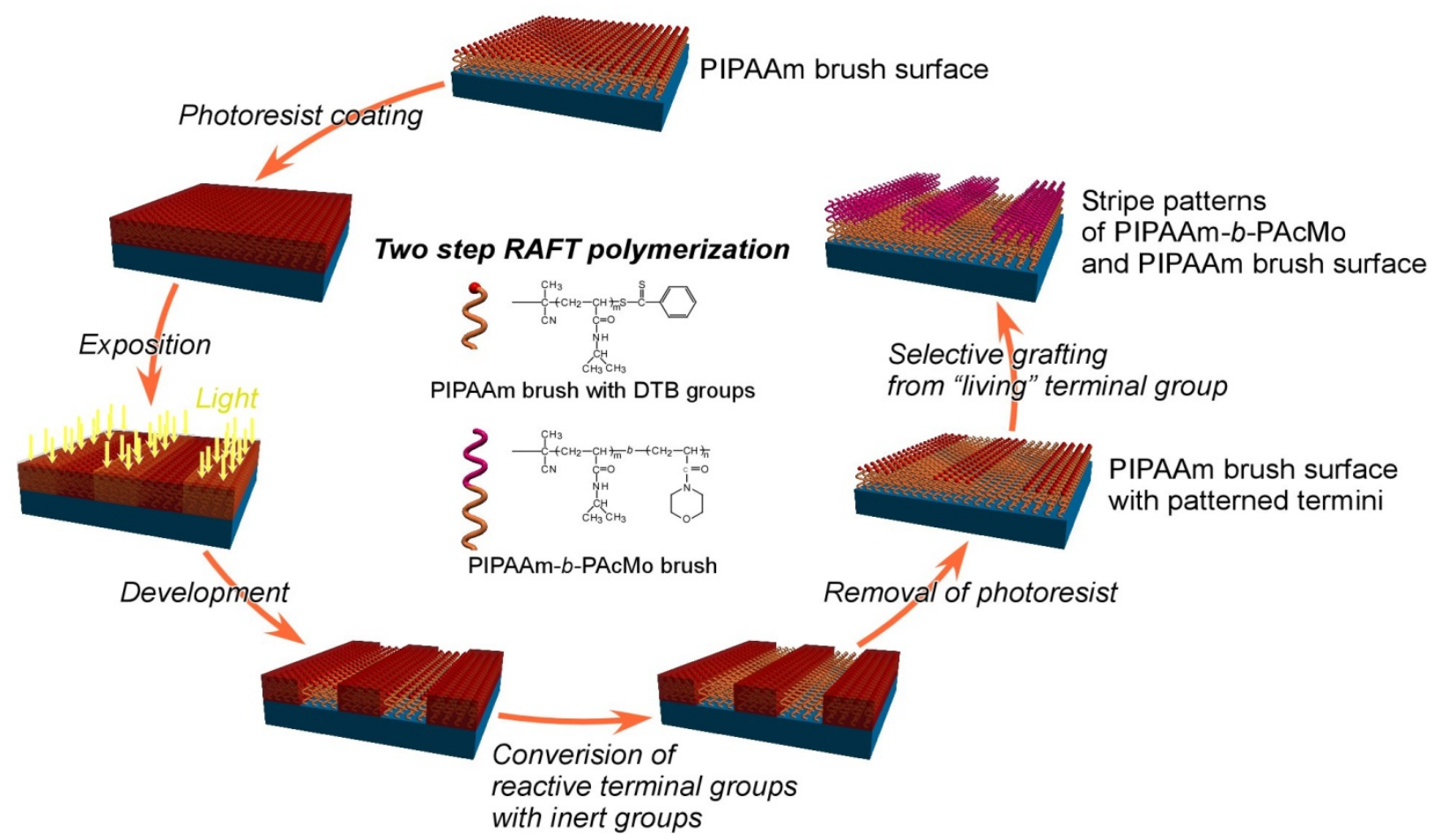

Normal human dermal fibroblasts (NHDFs) have been cultured on the micropatterned and non-patterned polymer brush surfaces at a density of $2 \times 10^{4}$ cells $/ \mathrm{cm}^{2}$. As shown in Figure 12a, 
NHDFs have adhered on a non-patterned polymer brush surface randomly. On the other hand, after $24 \mathrm{~h}$ culture, NHDFs have adhered on the PIPAAm brush regions of micropatterned surface and exhibited $100-\mu \mathrm{m}$ width stripes of cultured cells with a orientational structure (Figure 12b). Further studies have demonstrated that the orientations of cells are obtained on $50-\mu \mathrm{m}$ and $100-\mu \mathrm{m}$ stripe pattered surfaces. In contrast, NHDFs are unable to be orientated when the width of stripe regions was reduced to $25 \mu \mathrm{m}$. These results suggest that the pattern width is a key factor for cell orientation. The arrangement of NHDFs has been reserved after 5-day culture on a PIPAAm/PIPAAm- $b$-PAcMo patterned surface with a $50-\mu \mathrm{m}$ stripe, as well as a well-orientated cell sheet being fabricated on the micropatterned surface (Figure 12c). Furthermore, as shown in Figure 12d, actin filaments have significantly orientated in cell layers, suggesting that the cytoskeleton is also regulated by the designed micropatterning of polymer domains. Reducing temperature to $20{ }^{\circ} \mathrm{C}$, a cell sheet has been harvested from the micropatterned surface with a different shrinking rate in vertical and parallel directions of cell alignment (on an approximate aspect ratio of 3:1). These results suggest that the cell sheet can retain the orientation arrangement of cells, resulting in the mechanical and biological aspects of cell sheets after detachment from the functionalized temperature-responsive surfaces.

Figure 12. Phase contrast microscopic photographs of adhering normal human dermal fibroblasts (NHDFs) on (a) non-patterned PIPAAm brush surface and (b) a poly( $N$-isopropylacrylamide-block- $N$-acryloylmorpholine) (PIPAAm- $b$-PAcMo) patterned brush surface with $100 \mu \mathrm{m}$ width stripe patterns after $24 \mathrm{~h}$ cell culture. (c) Phase contrast microscopic image and (d) fluorescence image of adhering NHDF sheet on PIPAAm- $b$-PAcMo patterned brush surface with $50 \mu \mathrm{m}$ width stripe patterns after 5-day cell culture. Actin (red) and nuclei (blue) in aligned NHDFs on a patterned surface (d) are stained with AlexaFluor568-phalloidin (red) and Hoechst 33258 (blue), respectively. Scale bar: $100 \mu \mathrm{m}$.
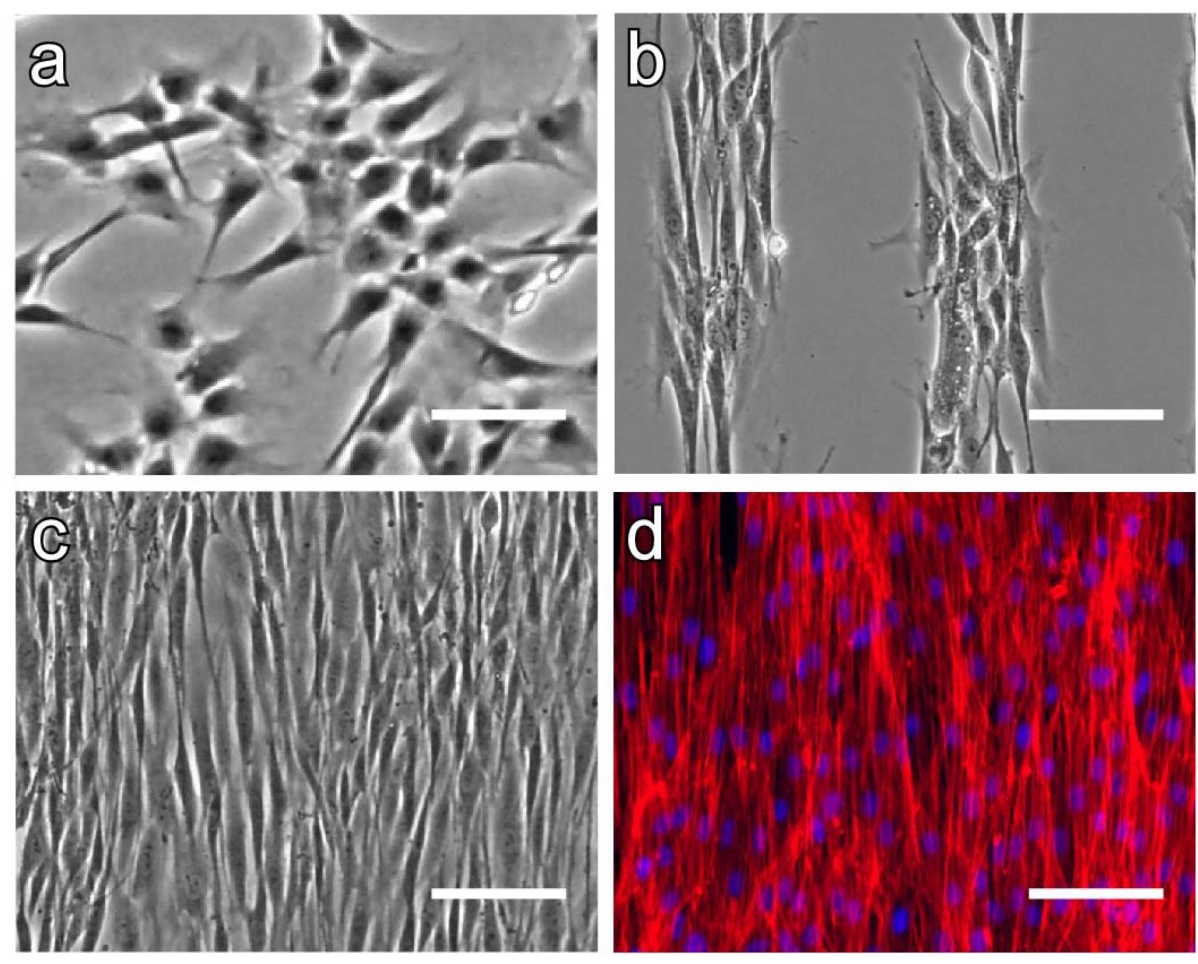


\section{Conclusions}

Our laboratory has proposed the cell sheet engineering technology by utilizing various temperature-responsive polymer modified surfaces. An intact cell sheet has successfully been harvested for fabricating a functional tissue without enzyme treatments. A cell sheet detachment process has been promoted by using a porous membrane, incorporating a hydrophilic moiety into the PIPAAm component, and a newly comb-type grafted PIPAAm gel. A manipulator device has been developed for handling the harvested cell sheet. Moreover, the modifications of temperature-responsive polymer grafted surfaces have been carried out for promoting their applications in cell sheet tissue engineering, such as enabling the co-culture of different species of cells with a pattered temperature-responsive surface, immobilizing bioactive molecules on a temperature-responsive surface for serum-free culture, and fabricating a high-orientational cell sheet on a micropatterned temperature-responsive polymer brush surface. The modification promises to obtain more complex tissue structures and functions by cell sheet engineering.

\section{Acknowledgements}

This study was partially supported by Creation of innovation centers for advanced interdisciplinary research areas Program in the Project for Developing Innovation Systems "Cell Sheet Tissue Engineering Center (CSTEC)" from the Ministry of Education, Culture, Sports, Science and Technology (MEXT), Japan.

\section{References}

1. Kopecek, J.; Vacik, J.; Lim, D. Permeability of membranes containing ionogenic groups. J. Polym. Sci. A Polym. Chem. 1971, 9, 2801-2815.

2. Tanaka, T.; Nishino, I.; Sun, S.-T.; Ueno-Nishio, S. Collapse of gels in an electric field. Science 1981, 218, 467-469.

3. Ishihara, K.; Muramoto, N.; Shinohara, I. Controlled release of organic substances using polymer membrane with responsive function for amino compounds. J. Appl. Polym. Sci. 1984, 29, 211-217.

4. Bae, Y.H.; Okano, T.; Kim, S.W. Temperature dependence of swelling of crosslinked poly(N,N-alkyl substituted acrylamides) in water. J. Polym. Sci. Polym. Phys. 1990, 28, 923-936.

5. Heskins, M.; Guillet, J.E. Solution properties of poly( $N$-isopropylacrylamide). J. Macromol. Sci. Chem. 1968, 2, 1441-1445.

6. Nakayama, M.; Okano, T. Intelligent thermoresponsive polymeric micelles for targeted drug delivery. J. Drug Del. Sci. Tech. 2006, 16, 35-44.

7. Kanazawa, H.; Yamamoto, K.; Matsushima, Y.; Takai, N.; Kikuchi, A.; Sakurai, Y.; Okano, T. Temperature-responsive chromatography using poly $(N$-isopropylacrylamide)-modified silicacells. Anal. Chem. 1996, 68, 100-105.

8. Kikuchi, A.; Okano, T. Intelligent thermoresponsive polymeric stationary phases for aqueous chromatography for biological compounds, Prog. Polym. Sci. 2002, 27, 1165-1193. 
9. Nagase, K.; Kobayashi, J.; Okano, T. Temperature-responsive intelligent interfaces for biomolecular separation and cell sheet engineering. J. R. Soc. Interface 2009, 6, S293-S309.

10. Yamada, N.; Okano, T.; Sakai, H.; Karikusa, F.; Sawasaki, Y.; Sakurai, Y. Thermo-responsive polymeric surfaces; control of attachment and detachment of cultured cells. Makromol. Chem. Rapid Commun. 1990, 11, 571-576.

11. Yang, J.; Yamato, M.; Kohno, C.; Nishimoto, A.; Sekine, H.; Fukai, F.; Okano, T. Cell sheet engineering: recreating tissues without biodegradable scaffolds. Biomaterials 2005, 26, 6415-6422.

12. Yamato, M.; Okano, T. Cell sheet engineering. Mater. Today 2004, 7, 42-47.

13. Matsuda, N.; Shimizu, T.; Yamato, M.; Okano, T. Tissue engineering based on cell sheet technology. Adv. Mater. 2007, 19, 3089-3099.

14. Yamato, M.; Akiyama, Y.; Kobayashi, J.; Yang, J.; Kikuchi, A.; Okano, T. Temperature-responsive cell culture surfaces for regenerative medicine with cell sheet engineering. Prog. Polym. Sci. 2007, 32, 1123-1133.

15. Shimizu, T.; Yamato, M.; Kikuchi, A.; Okano, T. Two-dimensional manipulation of cardiac myocyte sheets utilizing temperature-responsive culture dishes augments the pulsatile amplitude. Tissue Eng. 2001, 7, 141-151.

16. Kikuchi, A.; Okuhara, M.; Karikusa, F.; Sakurai, Y.; Okano, T. Two-dimensional manipulation of confluently cultured vascular endothelial cells using temperature-responsive poly( $N$-isopropyl-acrylamide)-grafted surfaces. J. Biomater. Sci. Polym. Ed. 1998, 9, 1331-1348.

17. Okano, T.; Yamada, N.; Sakai, H.; Sakurai, Y. A novel recovery system for cultured cells using plasma treated polystyrene dishes grafted with poly ( $N$-isopropylacrylamide). J. Biomed. Mater. Res. 1993, 27, 1243-1251.

18. Yamato, M.; Utsumi, M.; Kushida, A.; Konno, C.; Kikuchi, A.; Okano, T. Thermo-responsive culture dishes allow the intact harvest of multilayered keratinocyte sheets without dispase by reducing temperature. Tissue Eng. 2001, 7, 473-480.

19. Yamato, M.; Okuhara, M.; Karikusa, F.; Kikuchi, A.; Sakurai, Y.; Okano, T. Signal transduction and cytoskeletal reorganization are required for cell detachment from cell culture surfaces grafted with a temperature-responsive polymer. J. Biomed. Mater. Res. 1999, 44, 44-52.

20. Nishida, K.; Yamato, M.; Hayashida, Y.; Watanabe, K.; Maeda, N.; Watanabe, H.; Yamamoto, K.; Nagai, S.; Kikuchi, A.; Tano, Y.; Okano, T. Functional bioengineered corneal epithelial sheet grafts from corneal stem cells expanded ex vivo on a temperature-responsive cell culture surface. Transplantation 2004, 77, 379-385.

21. Nishida, K.; Yamato, M.; Hayashida, Y.; Watanabe, K.; Yamamoto, K.; Adachi, E.; Nagai, S.; Kikuchi, A.; Maeda, N.; Watanabe, H.; Okano, T.; Tano, Y. Corneal reconstruction with tissue-engineered cell sheets composed of autologous oral mucosal epithelium. New Engl. J. Med. 2004, 351, 1187-1196.

22. Kushida, A.; Yamato, M.; Isoi, Y.; Kikuchi, A.; Okano, T. A noninvasive transfer system for polarized renal tubule epithelial cell sheets using temperatureresponsive culture dishes. Eur. Cells Mater. 2005, 10, 23-30. 
23. Kushida, A.; Yamato, M.; Kikuchi, A.; Okano, T. Two-dimensional manipulation of differentiated Madin-Darby canine kidney (MDCK) cell sheets: The noninvasive harvest from temperature-responsive culture dishes and transfer to other surfaces. J. Biomed. Mater. Res. 2001, 54, 37-46.

24. Akizuki, T.; Oda, S.; Komaki, M.; Tsuchioka, H.; Kawakatsu, N.; Kikuchi, A.; Yamato, M.; Okano, T.; Ishikawa, I. Application of periodontal ligament cell sheet for periodontal regeneration: a pilot study in beagle dogs. J. Periodontal Res. 2005, 40, 245-251.

25. Hasegawa, M.; Yamato, M.; Kikuchi, A.; Okano, T.; Ishikawa, I. Human periodontal ligament cell sheets can regenerate periodontal ligament tissue in an athymic rat model. Tissue Eng. 2005, 11, 469-478.

26. Ohashi, K.; Yokoyama, T.; Yamato, M.; Kuge, H.; Kanehiro, H.; Tsutsumi, M.; Amanuma, T.; Iwata, H.; Yang, J.; Okano, T.; Nakajima, Y. Engineering functional two- and three-dimensional liver systems in vivo using hepatic tissue sheets. Nat. Med. 2007, 13, 880-885.

27. Shimizu, T.; Yamato, M.; Akutsu, T.; Shibata, T.; Isoi, Y.; Kikuchi, A.; Umezu, M.; Okano, T. Electrically communicating three-dimensional cardiac tissue mimic fabricated by layered cultured cardiomyocyte sheets. J. Biomed. Mater. Res. 2002, 60, 110-117.

28. Akiyama, Y.; Kikuchi, A.; Yamato, M.; Okano, T. Ultrathin poly( $N$-isopropylacrylamide) grafted layer on pulystyrene surfaces for cell adhesion/detachment control. Langmuir 2004, 20, $5506-5511$.

29. Kikuchi, A.; Okano, T. Nanostructured designs of biomedical materials: Applications of cell sheet engineering to functional regenerative tissues and organs. J. Control. Release 2005, 101, 69-84.

30. Takei, Y.G.; Aoki, T.; Sanui, K.; Ogata, N.; Sakurai, Y.; Okano, T. Dynamic contact angle measurement of temperature-responsive surface properties for poly( $N$-isopropylacrylamide) grafted surfaces. Macromolecules 1994, 27, 6163-6166.

31. Yakushiji, T.; Sakai, K.; Kikuchi, A.; Aoyagi, T.; Sakurai, Y.; Okano, T. Graft architectural effects on thermo-responsive wettability changes of poly( $N$-isopropylacrylamide)-modified surfaces. Langmuir 1998, 14, 4657-4662.

32. Fukumori, K.; Akiyama, Y.; Yamato, M.; Kobayashi, J.; Sakai, K.; Okano, T. Temperature-responsive glass coverslips with an ultrathin poly( $N$-isopropyl-acrylamide $)$ layer. Acta Biomater. 2009, 5, 470-476.

33. Waymouth, C. To disaggregate or not to disaggregate injury and cell disaggregation, transient or permanent? In Vitro 1974, 10, 97-111.

34. Osunkoya, B.O.; Mottram, F.C.; Isoun, M.J. Synthesis and fate of immunological surface receptors on cultured Burkitt lymphoma cells. Int. J. Cancer 1969, 4, 159-165.

35. Revel, J.P.; Hoch, P.; Ho, D. Adhesion of cultured cells to their substratum. Exp. Cell Res. 1974, 84, 207-218.

36. Kushida, A.; Yamato, M.; Konno, C.; Kikuchi, A.; Sakurai, Y.; Okano, T. Decrease in culture temperature releases monolayer endothelial cell sheets together with deposited fibronectin matrix from temperature-responsive culture surfaces. J. Biomed. Mater. Res. 1999, 45, 355-362.

37. Kondoh, H.; Sawa, Y.; Miyagawa, S.; Sakakida, K.; Memon, I.A.; Kawaguchi, N.; Matsuura, N.; Shimizu, T.; Okano, T.; Matsuda, H. Longer preservation of cardiac performance by sheet-shaped myoblast implantation in dilated cardiomyopathic hamsters. Cardiovasc. Res. 2006, 69, 466-475. 
38. Memon, A.I.; Sawa, Y.; Fukushima, N.; Matsumiya, G.; Miyagawa, S.; Taketani, S.; Sakakida, S.K.; Kondoh, H.; Aleshin, A.N.; Shimizu, T.; Okano, T.; Matsuda, H. Repair of impaired myocardium by means of implantation of engineered autologous myoblast sheets. J. Thorac. Cardiovasc. Surg. 2005, 130, 1333-1341.

39. Kwon, O.H.; Kikuchi, A.; Yamato, M.; Sakurai, Y.; Okano, T. Rapid cell sheet detachment from poly( $\mathrm{N}$-isopropylacrylamide)-grafted porous cell culture membranes. J. Biome. Mater. Res. 2000, 50, 82-89.

40. Kaneko, Y.; Nakamura, S.; Sakai, K.; Kikuchi, A.; Aoyagi, T.; Sakurai, Y.; Okano, T. Deswelling mechanism for comb-type grafted poly(N-isopropylacrylamide) hydrogels with rapid temperature responses. Polym. Gels Netw. 1998, 6, 333-345.

41. Kaneko, Y.; Nakamura, S.; Sakai, K.; Aoyagi, T.; Kikuchi, A.; Sakurai, Y.; Okano, T. Rapid deswelling response of poly( $N$-isopropylacrylamide) hydrogels by the formation of water release channels using poly(ethylene oxide) graft chains. Macromolecules 1998, 31, 6099-6105.

42. Kwon, O.H.; Kikuchi, A.; Yamato, M.; Okano, T. Accelerated cell sheet recovery by co-grafting of PEG with PIPAAm onto porous cell culture membranes. Biomaterials 2003, 24, 1223-1232.

43. Yoshida, R.; Uchida, K.; Kaneko, Y.; Sakai, K.; Kikuchi, A.; Sakurai, Y.; Okano, T. Comb-type grafted hydrogels with rapid de-swelling response to temperature changes. Nature 1994, 374, 240-242.

44. Kaneko, Y.; Sakai, K.; Kikuchi, A.; Sakurai, Y.; Okano, T. Fast swelling/deswelling kinetics of comb-type grafted poly( $N$-isopropylacrylamide) hydrogels. Macromol. Symp. 1996, 109, 41-53.

45. Tang, Z.; Akiyama, Y.; Yamato, M.; Okano, T. Comb-type grafted poly( $N$-isopropylacrylamide $)$ gel modified surfaces for rapid detachment of cell sheet. Biomaterials 2010, 31, 7435-7443.

46. Haraguchi, Y.; Shimizu, T.; Sasagawa, T.; Sekine, H.; Sakaguchi, K.; Kikuchi, T.; Sekine, W.; Sekiya, S.; Yamato, M.; Umezu, M.; Okano, T. Fabrication of functional three-dimensional tissues by stacking cell sheets in vitro. Nat. Protoc. 2012, 7, 850-858.

47. Bhatis, S.; Balis, U.; Yarmush, M.; Toner, M. Effect of cell-cell interactions in preservation of cellular phenotype: Cocultivation of hepatocytes and nonparenchymal cells. FASEB J. 1999, 13, 1883-1900.

48. Harimoto, M.; Yamato, M.; Kikuchi, A.; Okano, T. Cell sheet engineering: Intelligent polymer patterned surfaces for tissue engineered liver. Macromol. Symp. 2003, 195, 231-235.

49. Bae, Y.H.; Okano, T.; Kim, S.W. Temperature dependence of swelling of crosslinked poly $(N, N$-alkyl substituted acrylamides $)$ in water. J. Polym. Sci. Polym. Phys. 1990, 28, 923-936.

50. Takei, Y.G.; Aoki, T.; Sanui, K.; Ogata, N.; Okano, T.; Sakurai, Y. Temperature-responsive bioconjugates. 2. Molecular design for temperature-modulated bioseparations. Bioconjugate Chem. 1993, 4, 341-346.

51. Iwata, H.; Oodate, M.; Uyama, Y.; Amemiya, H.; Ikada, Y. Preparation of temperature-sensitive membranes by graft polymerization onto a porous membrane. J. Membr. Sci. 1991, 55, 119-130.

52. Feil, H.; Bae, Y.H.; Feijen, J.; Kim, S.W. Effect of comonomer hydrophilicity and ionization on the lower critical solution temperature of $\mathrm{N}$-isopropylacrylamide copolymers. Macromolecules 1993, 26, 2496-2500. 
53. Tsuda, Y.; Kikuchi, A.; Yamato, M.; Sakurai, Y.; Umezu, M.; Okano, T. Control of cell Adhesion and detachment using temperature and thermo-responsive copolymer grafted culture surfaces. J. Biomed. Mater. Res. 2004, 69A, 70-78.

54. Tsuda, Y.; Kikuchi, A.; Yamato, M.; Nakao, A.; Sakurai, Y.; Umezu, M.; Okano, T. The use of patterned dual thermoresponsive surfaces for the cullective recovery as co-cultured cell sheets. Biomaterials 2005, 26, 1885-1893.

55. Ebara, M.; Yamato, M.; Nagai, S.; Aoyagi, T.; Kikuchi, A.; Sakai, K.; Okano, T. Incorporation of new carboxylate functionalized co-monomers to temperature-responsive polymer-grafted cell surfaces. Surf. Sci. 2004, 570, 134-141.

56. Ebara, M.; Yamato, M.; Aoyagi, T.; Kikuchi, A.; Sakai, K.; Okano, T. Temperature-responsive cell culture surfaces enable "on-off" affinity control between cell integrins and RGDS ligands. Biomacromolecules 2004, 5, 505-510.

57. Yamada, K.M. Adhesive recognition sequences. J. Biol. Chem. 1991, 266, 12809-12812.

58. Hatakeyama, H.; Kikuchi, A.; Yamato, M.; Okano, T. Bio-functionalized thermoresponsive interfaces facilitating cell adhesion and proliferation. Biomaterials 2006, 27, 5069-5078.

59. Hatakeyama, H.; Kikuchi, A.; Yamato, M.; Okano, T. Patterned biofunctional designs of thermoresponsive surfaces for spatiotemporally controlled cell adhesion, growth, and thermally induced detachment. Biomaterials 2007, 28, 3632-3643.

60. Nishi, M.; Kobayashi, J.; Pechmann, S.; Yamato, M.; Akiyama, Y.; Kikuchi, A.; Uchida, K.; Textor, M.; Yajima, H.; Okano, T. The use of biotin-avidin binding to facilitate biomodification of thermoresponsive culture surfaces. Biomaterials 2007, 28, 5471-5476.

61. Takahashi, H.; Matsuzaka, N.; Nakayama, M.; Kikuchi, A.; Yamato, M.; Okano, T. Terminally functionalized thermoresponsive polymer brushes for simultaneously promoting cell adhesion and cell sheet harvest. Biomacromolecules 2012, 13, 253-260.

62. Nakayama, M.; Okano, T. Polymer terminal group effects on properties of thermoresponsive polymeric micelles with controlled outer-shell chain lengths. Biomacromolecules 2005, 6, 2320-2327.

63. McCormick, C.L.; Sumerlin, B.S.; Lokitz, B.S.; Stempka, J.E. RAFT-synthesized diblock and triblock copolymers: Thermallyinduced supramolecular assembly in aqueous media. Soft Matter 2008, 4, 1760-1773.

64. Takahashi, H.; Nakayama, M.; Itoga, K.; Yamato, M.; Okano, T. Micropatterned thermoresponsive polymer brush surfaces for fabricating cell sheets with well-controlled orientational structures. Biomacromolecules 2011, 12, 1414-1418.

(C) 2012 by the authors; licensee MDPI, Basel, Switzerland. This article is an open access article distributed under the terms and conditions of the Creative Commons Attribution license (http://creativecommons.org/licenses/by/3.0/). 